\title{
Improvement of Organic Soil Shear Strength through Calcite Precipitation Method Using Soybeans as Bio-Catalyst
}

\author{
Heriansyah Putra ${ }^{1, *(D)}$, Erizal ${ }^{1}$, Sutoyo ${ }^{1}$, Minson Simatupang ${ }^{2} \mathbb{D}$ and Dede Heri Yuli Yanto ${ }^{3}(\mathbb{D}$ \\ 1 Department of Civil and Environmental Engineering, IPB University, Bogor 16680, Indonesia; \\ erizal@apps.ipb.ac.id (E.); sutoyo@apps.ipb.ac.id (S.) \\ 2 Department of Civil Engineering, Halu Oleo University, Kendari 93232, Indonesia; \\ minson.simatupang@uho.ac.id \\ 3 Research Center for Biomaterials, Indonesian Institute of Sciences (LIPI), Cibinong 16911, Indonesia; \\ dede@biomaterial.lipi.go.id \\ * Correspondence: heriansyahptr@apps.ipb.ac.id
}

check for updates

Citation: Putra, H.; Erizal; Sutoyo; Simatupang, M.; Yanto, D.H.Y. Improvement of Organic Soil Shear Strength through Calcite Precipitation Method Using Soybeans as Bio-Catalyst. Crystals 2021, 11, 1044. https://doi.org/10.3390/cryst11091044

Academic Editors: Hamed

Khodadadi Tirkolaei,

Satoru Kawasaki, Liang Cheng and Leon van Paassen

Received: 27 July 2021

Accepted: 27 August 2021

Published: 30 August 2021

Publisher's Note: MDPI stays neutral with regard to jurisdictional claims in published maps and institutional affiliations.

Copyright: (C) 2021 by the authors Licensee MDPI, Basel, Switzerland This article is an open access article distributed under the terms and conditions of the Creative Commons Attribution (CC BY) license (https:// creativecommons.org/licenses/by/ $4.0 /)$.
Abstract: Organic soil has a high content of water and compressibility. Besides that, it has a low specific gravity, density, and shear strength. This study evaluates the applicability of the soybean crude urease for calcite precipitation (SCU-CP) method and its effectiveness in organic soil as a soil-amelioration technique. Various soybean concentrations were mixed with a reagent composed of urea and calcium chloride to produce the treatment solution. Its effect on the hydrolysis rate, $\mathrm{pH}$, and amount of precipitated calcite was evaluated through test-tube experiments. SEM-EDS tests were performed to observe the mineralogy and morphology of the untreated and treated samples. The treatment solution composed of the reagent and various concentrations of soybeans was applied to organic soil. The increasing strength of the organic soil was evaluated using direct shear (DS) and unconfined compression (UCS) tests. The test-tube results show that a hydrolysis rate of $1600 \mathrm{u} / \mathrm{g}$ was obtained when using $50 \mathrm{~g} / \mathrm{L}$ of soybeans with a precipitation ratio of $100 \%$. The mechanical tests show a significant enhancement in the parameters of the organic soil's shear strength. A shear strength improvement of 50\% was achieved in this study. A UCS of $148 \mathrm{kPa}$ and cohesion of $50 \mathrm{kPa}$ was obtained in the treated samples of organic soil. This research elucidates that the SCU-CP is an effective technique for improving organic soil's shear strength.

Keywords: calcite precipitation; hydrolysis rate; shear strength; soybean; SCU-CP; organic soil

\section{Introduction}

Organic soil has high compressibility, high saturation, low density, and low shear strength, resulting in massive and long-term deformation [1,2]. These characteristics bring about certain problems and limitations for the development of civil structures, especially in the geotechnical field. Several potential methods have been proposed for improving the parameters of organic soil, e.g., compaction, deep mixing, stone columns, and the grouting method using fly ash, cement, sodium silica, and calcite [2-12]. However, the aforementioned methods involve significant efforts, high costs, and a long span of time for application, resulting in low efficacy [13]. The utilization of chemicals has also caused significant environmental impacts, e.g., increasing the soil $\mathrm{pH}$ and contaminating the soil [14-16]. In addition, high viscosity and rapid chemical reactions in the chemical grouting have been known to reduce the effectivity of this method because the resulting cement fills the pores and hence, limits the area of improvement [17]. A grouting method using calcite, called enzyme-induced calcite precipitation (EICP), was introduced as a promising choice for the soil-enhancement approach [18-22]. The EICP method has been stated to be able to significantly ameliorate both the shear and the unconfined compressive strength of the soil. They range from $50 \mathrm{kPa}$ to $1.6 \mathrm{MPa}[19,20,23-25]$. Moreover, the 
utilization of EICP in sandy soil was reported to have reduced the permeability of the soil $[18,26]$.

Recently, the EICP method, using a urease enzyme (E1.12) purified from jack beans, was used as a bio-catalyst in the calcite precipitation method to produce calcite crystals $[18,19]$. The utilization of a commercial urease enzyme with this method leads to a significant financial burden $[27,28]$. Almajed et al. [28] noted that the utilization of a urease enzyme purified from the jack bean meal involves high costs. Hence, alternative materials to replace the commercial urease enzyme should be seriously considered. Some studies have been performed to look at other sources that can produce urease enzymes, such as cabbage [27], watermelon [22,29], jack beans [30], and soybeans [31-33]. It was reported that the utilization of urease harvested from crude soybean is a prospective catalyst, using the calcite precipitation $(\mathrm{CP})$ approach in refining soil $[32,33]$. Using soybean crude urease (SCU), hereafter in this paper referred to as SCU-CP, could upgrade the strength of the fine-grained soil to twice that of the untreated soil [32]. The improvement in the deviator strength of the SCU-CP-treated soil varied from $30 \mathrm{kPa}$ to $170 \mathrm{kPa}$ [32].

The calcite precipitation method has been extensively investigated to evaluate its efficacy in improving the strength of sandy soil $[18,22,25,34,35]$. However, its utilization with organic soil has been very limited. Similar research has been reported by Sidik et al. [36], Canakci et al. [37], and Chen et al. [38], who used microbial-induced calcite precipitation to improve organic soil's shear strength. The amount of enhancement in the organic soil's strength was lower than that of the sandy soil $[37,38]$. Other results showed an improvement of around $20 \%$ in the UCS of the bacterial-based calcite-improved organic soil $[36,39]$. The mass of the precipitated calcite within the soil was higher for the sandy soil than for the organic soil. This was because of the organic and chemical composition in the organic soil $[36,38]$. However, the study of the calcite precipitation method using soybean crude urease as the catalyst to improve the strength of organic soil has not been discussed in previous studies.

This research aims to assess the applicability of the SCU-CP method to enhance organic soil strength. The reaction rate and $\mathrm{pH}$ change during the urea hydrolysis and their effect on the production of precipitated calcite are evaluated through test-tube experiments. The improvement in the organic soil's shear strength is evaluated using direct shear (DS) and unconfined compression (UCS) tests. The mineralogical and morphological characteristics of the precipitated mineral and treated soil samples are also observed using SEM-EDS (Scanning Electron Microscopy with Energy Dispersive Spectroscopy).

\section{Materials and Methods}

\subsection{Materials}

This study observed organic soil collected from Siak, Province of Riau, Indonesia. The organic soil samples were prepared following Canakci et al. [40]. All the samples were sieved, and the soil that passed through sieve no. $100(0.15 \mathrm{~mm})$ was used in this study, as depicted in Figure 1. Soil property tests were performed to observe the characteristics of the organic soil. The soil was categorized as organic clay $(\mathrm{OH})$ by the Unified Soil Classification System (USCS) [41]. It had an organic content of $56.58 \%$, a D10 of $0.11 \mathrm{~mm}$, and a liquid limit of $126.25 \%$. The grain size distribution and physical properties of the organic soil used in this study are shown in Figure 2 and Table 1, respectively. In addition, the treatment solution was prepared by mixing the reagent and the catalyst. The reagent was prepared by combining the urea and $\mathrm{CaCl}_{2}$ with $95 \%$ purity taken from Kanto Chemicals, Tokyo, Japan. Soybean flour with No. 1031P-BIOCert/LSO-006-IDN/05 /17, obtained from Gasol Pertanian Organik, was used as the biocatalyst in this study. 


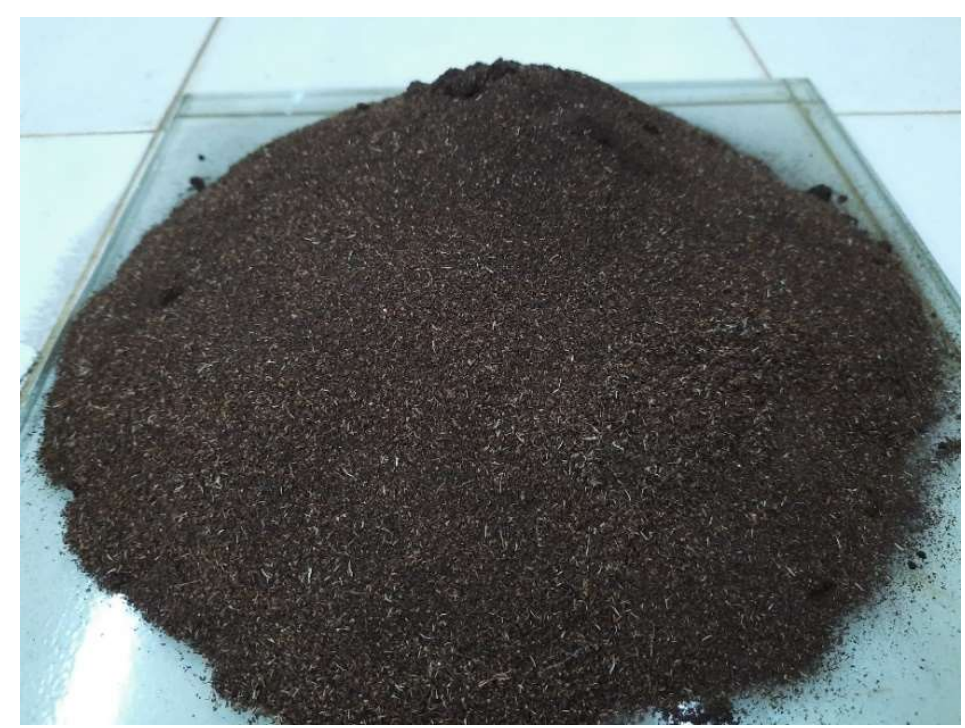

Figure 1. Organic soil used in this study.

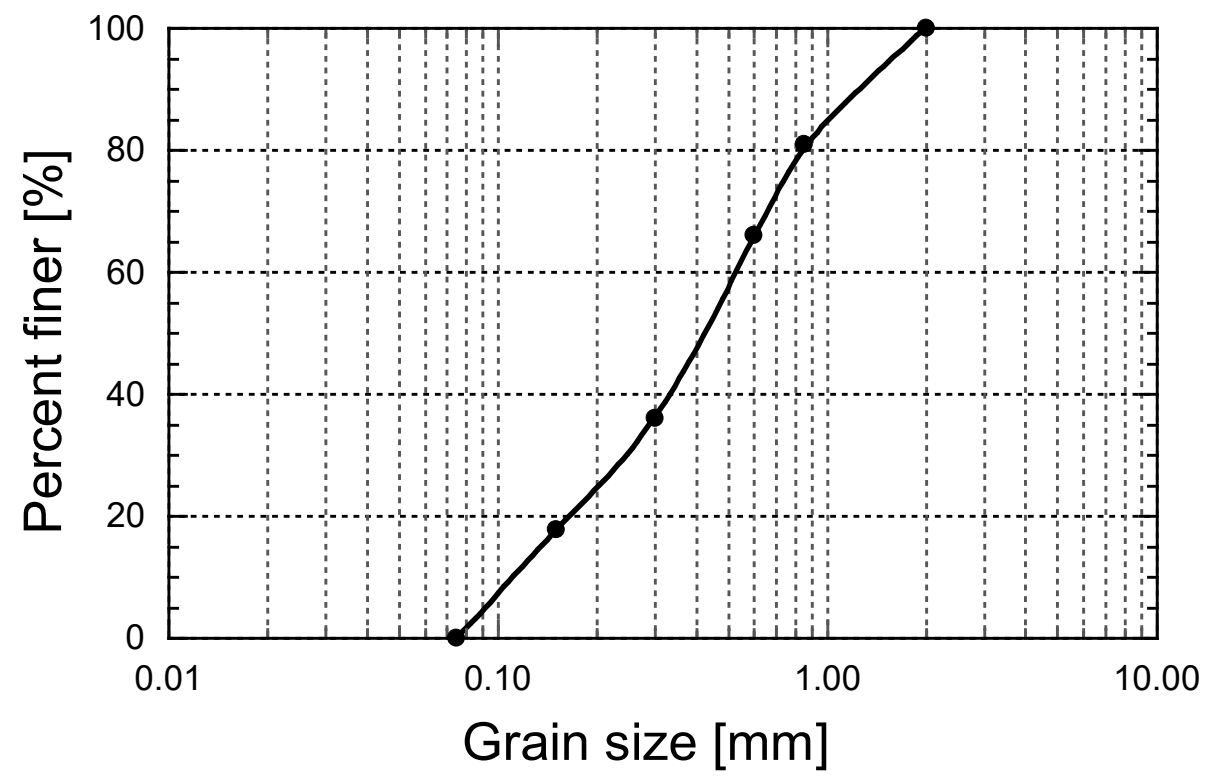

Figure 2. Grain-size distribution of the organic soil used in this study.

Table 1. Physical properties of the organic soil used in this study.

\begin{tabular}{ccc}
\hline Property & Value & Unit \\
\hline Specific gravity, Gs & 1.61 & - \\
Mean size, D10 & 0.11 & $\mathrm{~mm}$ \\
Uniformity coefficient, $C u$ & 4.88 & - \\
Curvature coefficient, $C c$ & 1.05 & - \\
Organic content & 56.58 & $\%$ \\
Ash content & 43.42 & $\%$ \\
Liquid limit, $L L$ & 126.25 & $\%$ \\
Plastic limit, $P L$ & Non-plastic $(N P)$ & - \\
Soil type & Organic clay $(O H)$ &
\end{tabular}




\subsection{Analysis of Hydrolysis Rate}

Hydrolysis rate determinations took place to assess the efficacy of the soybeans in changing the urea to carbonate and ammonia ions. This study adopted the research steps constructed by Whiffin et al. [42]. A standardized curve was prepared by specifying the conductivity outcoming from the whole hydrolysis of any urea's concentrations, from $50 \mathrm{mmol} / \mathrm{L}$ to $500 \mathrm{mmol} / \mathrm{L}$, that were hydrolyzed by $15 \mathrm{~g} / \mathrm{L}$ of soybean powder. The change in the conductivity with time was determined by Hanna Edge Multiparameter 230 and various concentrations of soybean powder, namely, 5, 10, 20, 30, 40, and $50 \mathrm{~g} / \mathrm{L}$. The rate of hydrolysis was measured by computing the conductivity gradient alterations against time and the curve of the standard curve, expressed in Equation (1).

$$
\text { Hydrolysis rate }\left(\frac{\mathrm{u}}{\mathrm{g}}\right)=\frac{\theta_{m s}}{\theta_{s c}} \cdot v \cdot N
$$

$\theta_{m s}$ is the sample gradient, $\theta_{s c}$ is the standardized curve gradient, $v$ is the sample volume $(\mathrm{L})$, and $N$ is the final ammonia concentration $(\mathrm{mmol} / \mathrm{L})$.

$\mathrm{pH}$ measurements were also conducted in this study to observe the hydrolysis process of urea. The determination of the $\mathrm{pH}$ evolution with time might indirectly define the rates and the magnitude of the urea hydrolysis [23]. The tests were conducted using a pH meter of the Hanna Edge Multiparameter 230. Various concentrations of soybean solutions were prepared and mixed with $1 \mathrm{~mol} / \mathrm{L}$ of urea to obtain $100 \mathrm{~mL}$ volume in total. The $\mathrm{pH}$ changes were recorded until the $\mathrm{pH}$ reached a constant value. During the measurements, the solution was stirred at a constant speed, and a change in temperature was also observed.

\subsection{Precipitation Test}

Tests of precipitation were performed to evaluate the efficacy of soybeans as a catalyst for producing precipitated calcite. The tests adapted the procedures promoted by Neupane et al. [19]. The reagent was composed of urea and calcium chloride, which were mixed separately with water, comprising $50 \%$ of the final volume of the treatment solution. The soybean powder was mixed with water for $5 \mathrm{~min}$ at a constant speed with a magnetic stirrer to prepare the other $50 \%$ of the final volume of the treatment solution. Thus, the reagent and soybean solution were mixed thoroughly to make a total volume of $30 \mathrm{~mL}$. The treatment solution was allowed to react for a curing time of seven days in a transparent tube at a room temperature of $25^{\circ} \mathrm{C}$. The precipitated mass was evaluated at the end of the time for curing using filter paper. The filtered treatment solution was then dried in a $60{ }^{\circ} \mathrm{C}$ oven for $24 \mathrm{~h}$. This way, the mass of calcite could be calculated.

\subsection{Soil Treatment}

Soil treatment was conducted to evaluate the improvement in the soil shear strength parameters of the organic soil after treating it with a mixed solution consisting of the reagent and soybean powder. The strength of the treated soil was assessed using a strength test of both unconfined compressive and direct shear, UCS and DS, respectively. The organic soil samples were prepared and combined with a controlled volume of treatment solution. The UCS test samples were created by the compaction of each soil sample into five layers with a total height and diameter of $10 \mathrm{~cm}$ and $5 \mathrm{~cm}$, respectively, to control the uniformity of the density of the sample. The direct shear test samples were prepared in two layers with a total height of $2 \mathrm{~cm}$ and a diameter of $6 \mathrm{~cm}$. Then, the treated samples were cured for seven days. A dry density of $0.6 \mathrm{~g} / \mathrm{cm}^{3}$ and a degree of saturation of $100 \%$ controlled the mass of each soil sample and the volume of the treatment solution mass.

$\mathrm{pH}$ measurements were also performed to evaluate the change in $\mathrm{pH}$ of the improved samples. This research followed the experimental procedures from ASTM D2976 [43]. Treated samples were collected from the UCS and direct shear tests. At various concentrations of soybeans, $3 \mathrm{~g}$ of treated soil were prepared and mixed with $50 \mathrm{~mL}$ of the calcium chloride solution with a concentration of $0.01 \mathrm{~mol} / \mathrm{L}$ for $30 \mathrm{~min}$. The evolution of $\mathrm{pH}$ was 
observed using the Hanna Edge Multiparameter 230 until the $\mathrm{pH}$ reached a constant value. SEM-EDS (Scanning Electron Microscopy with Energy Dispersive Spectroscopy) analyses were also performed to assess the mineral composition, the shape of the precipitated material, and its characteristics in the organic soil samples.

\section{Results and Discussion}

\subsection{Hydrolysis Rate}

A hydrolysis rate analysis was conducted to evaluate the efficacy of soybeans in hydrolyzing urea. Various concentrations of urea, namely, 50, 100, 200, 300, and $500 \mathrm{mmol} / \mathrm{L}$, were compounded with $15 \mathrm{~g} / \mathrm{L}$ of soybeans. The evolution of the conductance was measured until all of the urea was hydrolyzed. This was indicated by the conductance reaching the maximum value. Next, the maximum conductance values were plotted to produce a standard curve for hydrolysis, as depicted in Figure 3. Then, 1 mol of urea was prepared and mixed with various concentrations of soybean powder of 5, 10, 20, 30, 40, and $50 \mathrm{~g} / \mathrm{L}$. The conductance measurements were performed for $10 \mathrm{~min}$, and the results were plotted on a curve for the measured conductance. The change in conductance with time is shown in Figure 4.

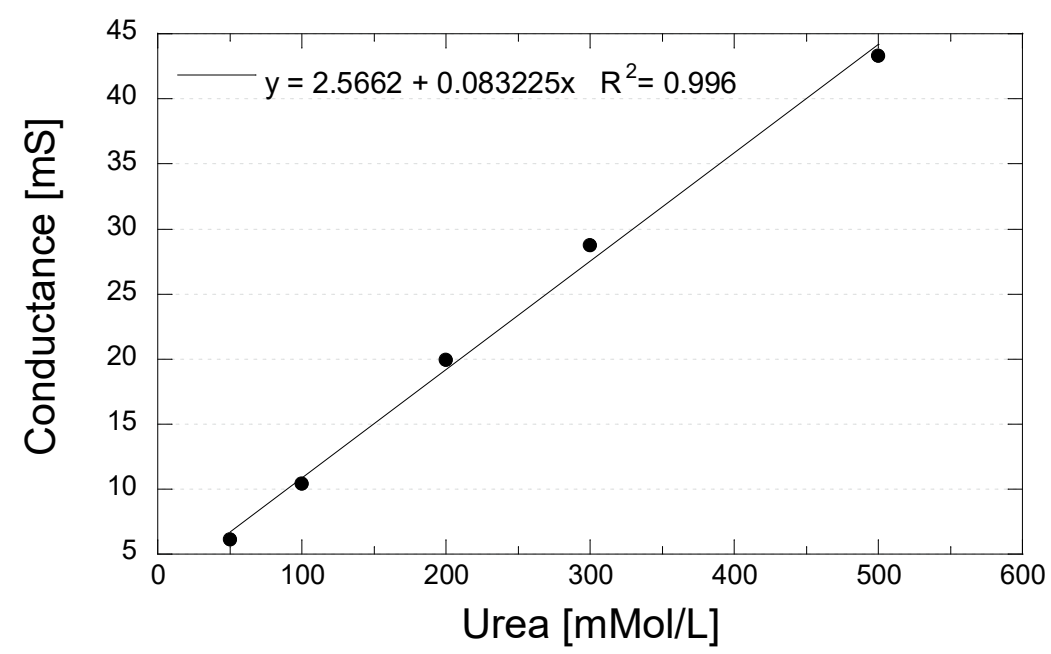

Figure 3. Standard curve of hydrolysis.

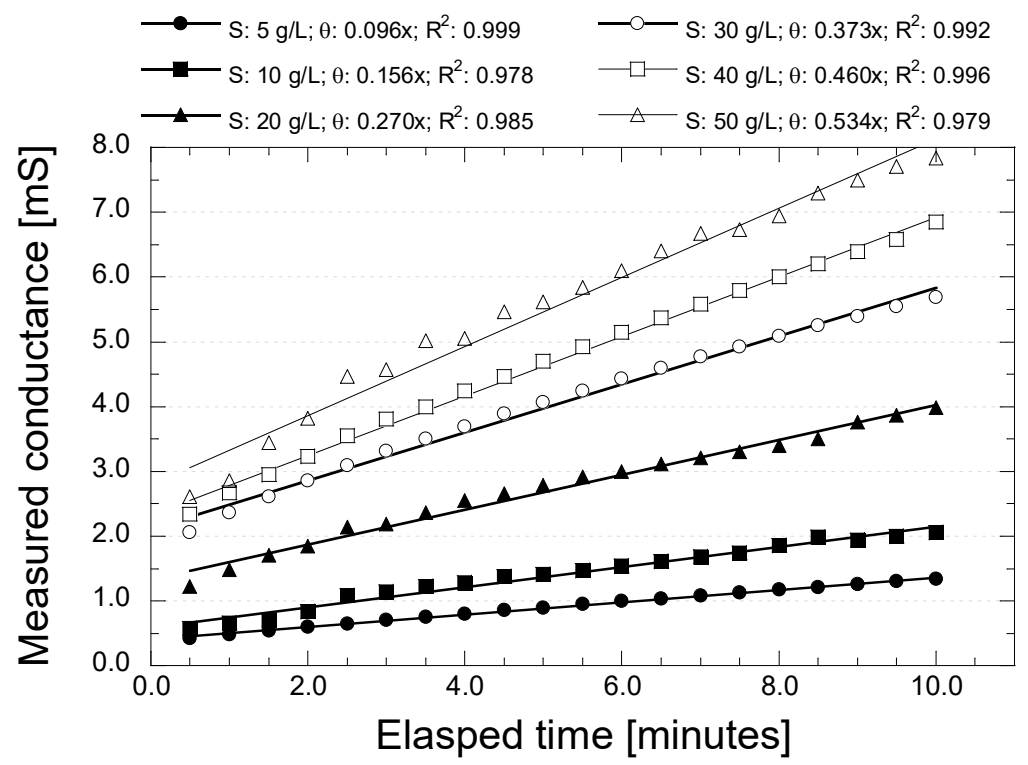

Figure 4. Change in conductance with time for various concentrations of soybeans. 
The conductance measurements were performed for various concentrations of soybeans, resulting in a linear curve with a slope. The slopes of the curves were then compared to the standard curve to obtain the hydrolysis rate depicted in Figure 5. As is apparent, the activity was linearly related to the increase in soybean concentration. The hydrolysis rate of $1600 \mathrm{u} / \mathrm{g}$ (note that $1 \mathrm{u}$ of activity corresponds to $1 \mu \mathrm{mol} / \mathrm{L}$ of urea hydrolyzed per minute) was obtained using $50 \mathrm{~g} / \mathrm{L}$ of soybeans. On average, the use of $1 \mathrm{~g} / \mathrm{L}$ of soybeans was estimated to have an activity of around $40 \mathrm{u} / \mathrm{g}$. Compared to commercial enzymes that have an activity of $2950 \mathrm{u} / \mathrm{g}$ for $15 \mathrm{~g} / \mathrm{L}$ (or around $200 \mathrm{u} / \mathrm{g}$ for $1 \mathrm{~g} / \mathrm{L}$ of urease) or other plant-derived ureases (i.e., watermelon [22], cabbage, soy pulp [27]), $5 \mathrm{~g} / \mathrm{L}$ of soybeans is high enough to be used instead of commercial urease enzymes with the EICP method.

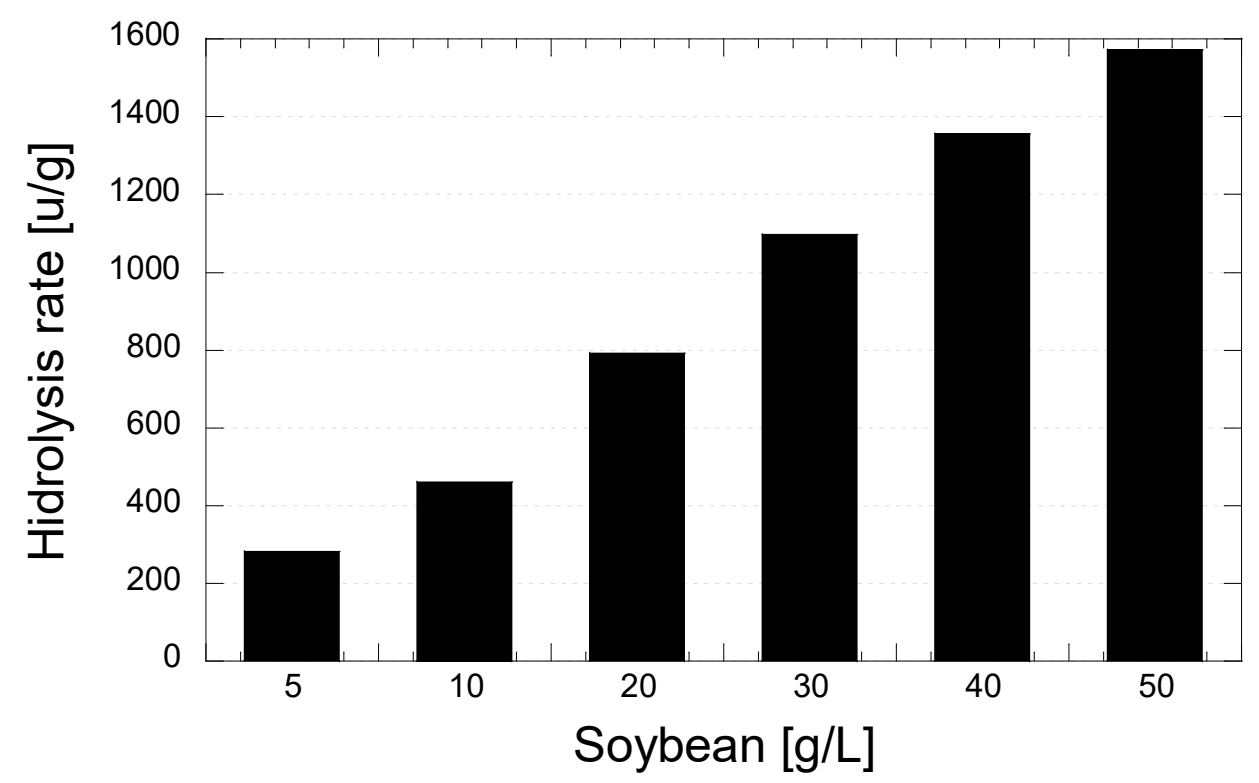

Figure 5. Hydrolysis rate results.

The $\mathrm{pH}$ measurements were taken to observe the elapsed time of the hydrolysis of urea using soybeans. The results of these measurements are depicted in Figure 6.

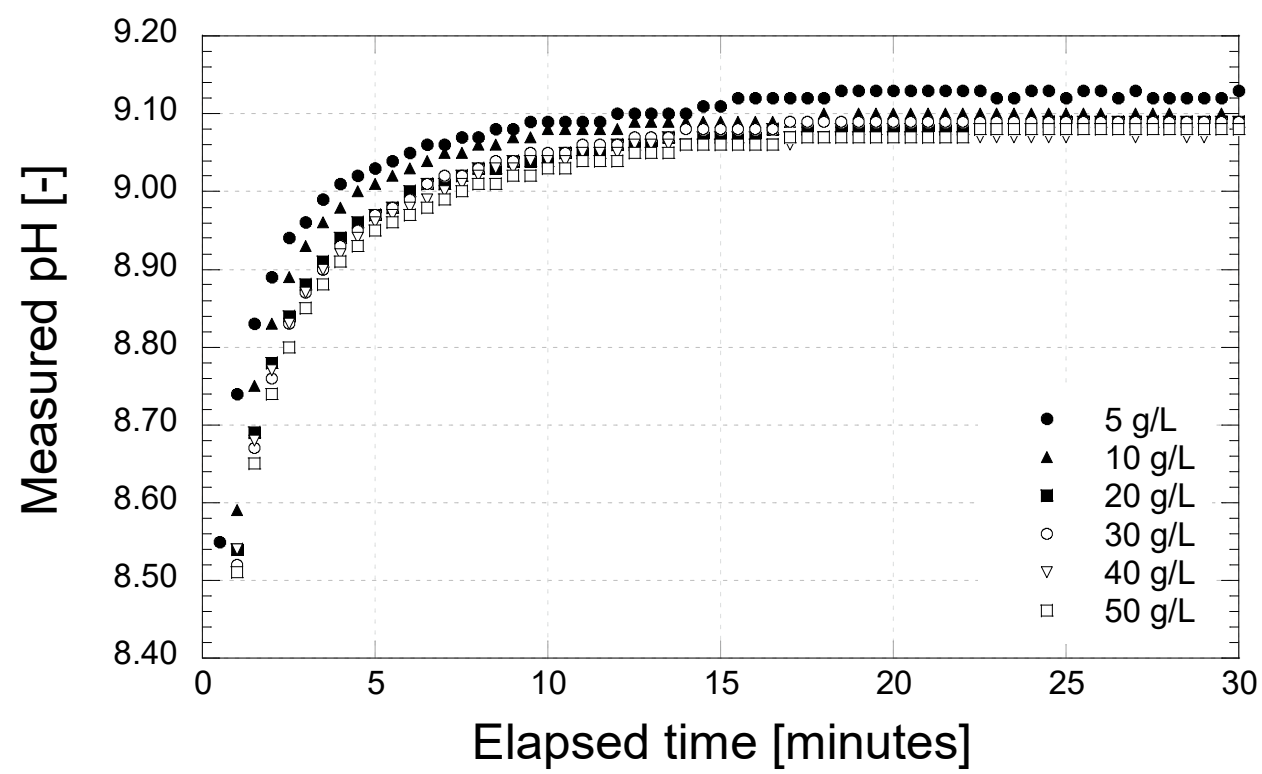

Figure 6. pH measurements with time for various concentrations of soybeans. 
The results show a significant improvement in the $\mathrm{pH}$ value at the beginning of mixing. It reached a constant value after $30 \mathrm{~min}$, in the range of 9.08 to 9.12 , depending on the soybean concentration. The increasing $\mathrm{pH}$ indicates the change in urea to carbonate and ammonia ions by means of hydrolysis. The released ammonia $\left(\mathrm{NH}_{4}\right)$ ions promoted the increase in $\mathrm{pH}$ [44]. Furthermore, the constant value of the $\mathrm{pH}$ confirms the completion of the reaction. The entire amount of urea was converted to carbonate and ammonia ions. The results of the $\mathrm{pH}$ measurements also show a decrease in the activity of the enzymes when the $\mathrm{pH}$ was 9 [45]. In addition, the $\mathrm{pH}$ results indicate that the concentration of soybeans had no significant impact on the $\mathrm{pH}$. A relatively similar $\mathrm{pH}$ was obtained for the various concentrations of soybeans, ranging from 5 to $50 \mathrm{~g} / \mathrm{L}$, resulting in $\mathrm{pH}$ levels ranging from 9.08 to 9.12 .

\subsection{Precipitation Test}

The precipitation tests were performed to evaluate the efficacy of the SCU-CP method by measuring the mass of the produced calcite. This test adopts the experimental procedure developed by Neupane et al. [19]. First, soybean and reagent solutions were prepared separately. Next, the reagent composed of urea and calcium chloride, each with concentrations of $0.5,1.0$, and $1.5 \mathrm{~mol} / \mathrm{L}$, and soybeans with various concentrations of 5 to $50 \mathrm{~g} / \mathrm{L}$, were prepared and mixed with distilled water separately. Then, $30 \mathrm{~mL}$ total volume of both soybean and reagent solution were mixed in a transparent tube and cured for three days. The conditions of the precipitation tests are depicted in Table 2. The precipitated materials were evaluated after the curing times. Firstly, the treatment solution was filtrated using filter paper No. 41 (pore size of $20 \mu \mathrm{m}$ ) to collect the material deposits. Next, the retained material was dried in an oven at $60^{\circ} \mathrm{C}$ for $24 \mathrm{~h}$ to enable the evaluation of the dry mass. Then, its productivity was examined as percentages of the precipitated material's dry mass, and the maximum theoretical mass for each concentration was calculated.

Table 2. Condition of the precipitation test.

\begin{tabular}{ccc}
\hline Case & Concentration of Reagent $(\mathbf{m o l} / \mathbf{L})$ & Concentration of Soybeans $(\mathrm{g} / \mathrm{L})$ \\
\hline S1.1 & 0.50 & 5 \\
S1.2 & 0.50 & 10 \\
S1.3 & 0.50 & 20 \\
S1.4 & 0.50 & 30 \\
S1.5 & 0.50 & 40 \\
S1.6 & 0.50 & 50 \\
\hline S2.1 & 1.00 & 5 \\
S2.2 & 1.00 & 10 \\
S2.3 & 1.00 & 20 \\
S2.4 & 1.00 & 30 \\
S2.5 & 1.00 & 40 \\
S2.6 & 1.00 & 50 \\
S3.1 & 1.50 & 5 \\
S3.2 & 1.50 & 10 \\
S3.3 & 1.50 & 20 \\
S3.4 & 1.50 & 30 \\
S3.5 & 1.50 & 40 \\
S3.6 & 1.50 & 50 \\
\hline
\end{tabular}

The productivity of the various concentrations of soybeans and reagents in producing a precipitated material is shown in Figure 7 . The precipitation ratio significantly increased when the concentration of soybean was increased from 5 to $20 \mathrm{~g} / \mathrm{L}$. Then, the precipitation mass reached a stable condition even when the soybean concentrations were enhanced. The increase in soybean concentration was seen to promote an improvement in the hydrolysis rates, and thus, it enhanced the calcite mass. In addition, the various concentrations of the reagent resulted in a different trend in the calcite mass. The increasing reagent 
concentration brought about a lower precipitation ratio in the same soybean concentration. These results indicate that soybean concentration is a crucial parameter in this method. Hence, the optimum concentration of reagent and soybeans should be considered. The increase in the concentration of the reagent from 0.5 to $1.5 \mathrm{~mol} / \mathrm{L}$ should be followed by the enhancement of the concentration of soybean from 5 to $30 \mathrm{~g} / \mathrm{L}$. Neupane et al. [19] noted that the upgrade in urease concentration had a notable influence on the precipitation ratio in the calcite precipitation method. Furthermore, this study shows that a high concentration of soybeans was able to inhibit the precipitation process. The precipitation ratio decreased from 90 to $95 \%$ when 40 to $50 \mathrm{~g} / \mathrm{L}$ of soybeans were appended to the solution. The organic content may affect this phenomenon, resulting in undissolved soybeans, hampering the precipitation process. Hence, a method to isolate the undissolved soybeans should be considered in order to optimize the use of soybeans as a bio-catalyst.

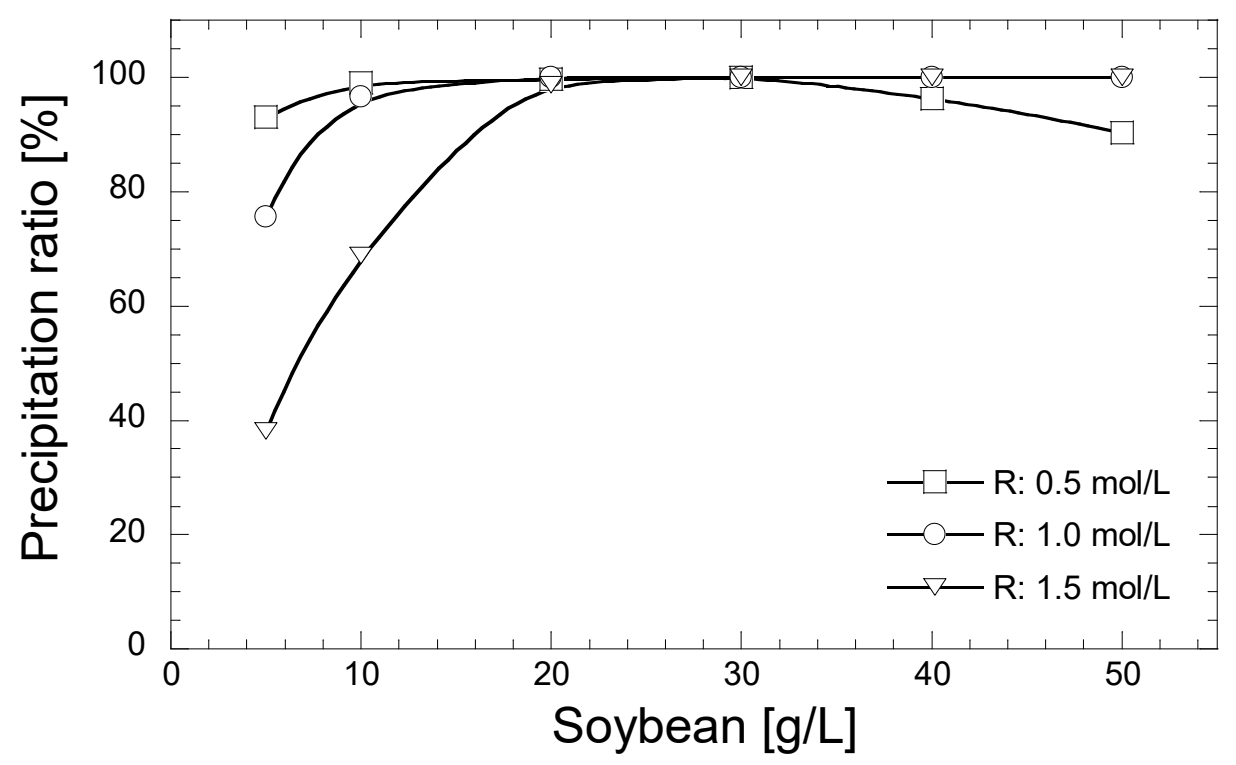

Figure 7. Precipitation test results with various concentrations of soybeans and reagent.

\subsection{Direct Shear (DS) Test}

DS tests were established to assess the effectiveness of SCU-CP on the organic soil's cohesion and internal friction angle. A reagent solution composed of $1.0 \mathrm{~mol} / \mathrm{L}$ of urea and $1.0 \mathrm{~mol} / \mathrm{L}$ of calcium chloride was prepared and then mixed thoroughly with the selected soybean solutions of 10, 20, and $30 \mathrm{~g} / \mathrm{L}$. Each soil sample was mixed with the treatment solution, and thus, the mold sample was formed. The soil sample was controlled under saturated conditions with a dry density of $0.6 \mathrm{~g} / \mathrm{cm}^{3}$. The untreated soil samples were also prepared in the same way using a controlled volume of water. All the samples were cured for seven days, and then DS tests were conducted under vertical stress in the order of 50 , 100 , and $150 \mathrm{kPa}$.

The results of the DS tests on the organic soil treated by the calcite precipitation solution with various soybean concentrations are depicted in Figure 8. The results show that the cohesion levels of the improved soil were augmented significantly. Improvements in cohesion, ranging from 43 to $79 \%$ compared to the untreated soil, were obtained for the various soybean concentrations. Increasing the soybean concentration also led to an improvement in cohesion. The treatment solution composed of the reagent and soybeans was able to promote calcite precipitation and the strengthening of the soil particles. In comparison, the improvement in the strength gained in this research was significantly higher than that in bacterial-based calcite precipitation techniques $[36,38]$. The results confirm that the application of soybeans might be more effective than bacteria. This could be due to the activity of susceptible bacteria and influenced by environmental 
conditions [46]. In addition, it was shown that a lower $\mathrm{pH}$ hampered the bacterial activity, thus reducing the hydrolysis process [47].

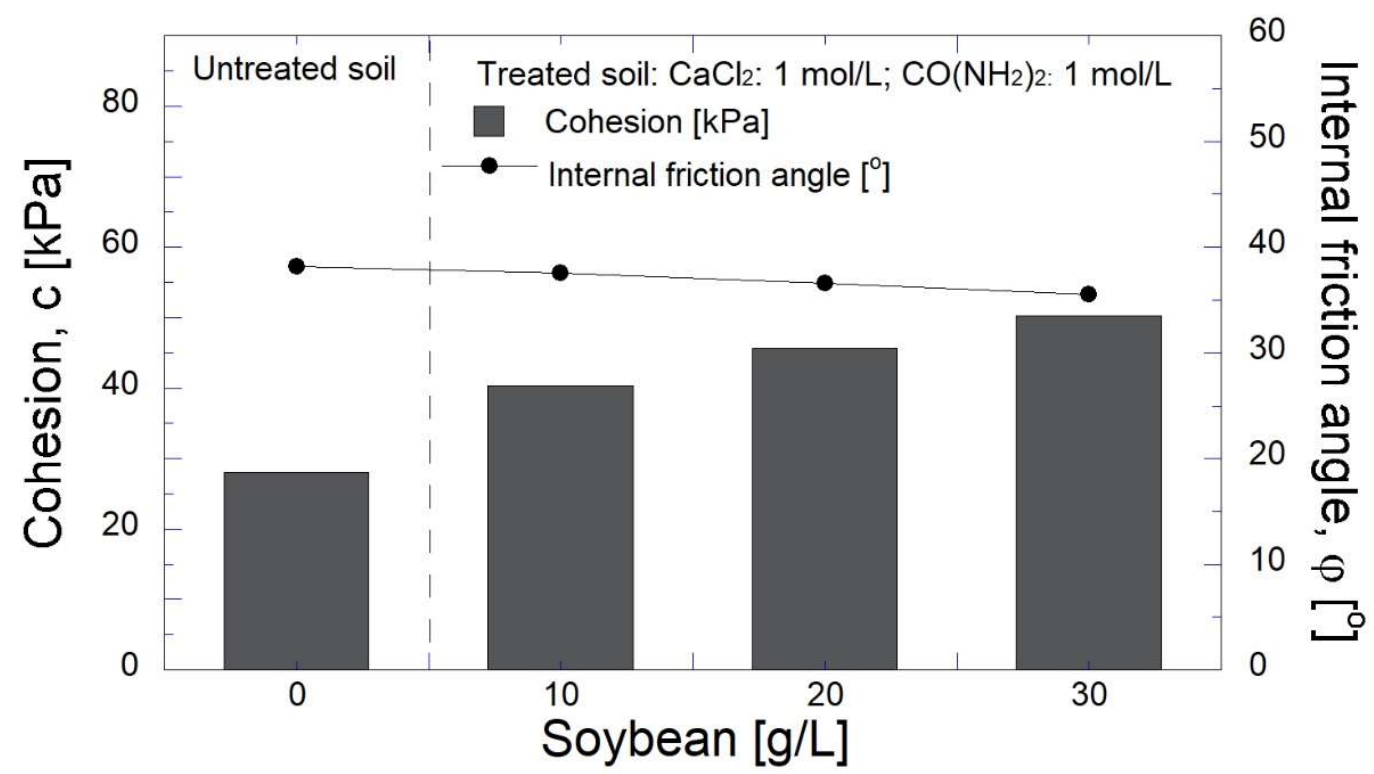

Figure 8. Direct shear test results with various concentrations of soybeans.

Furthermore, the treatment of organic soil using precipitation was seen to have no significant effect on the internal friction angle. The precipitated material within the soil caused a slight decrease in the friction of the soil. Putra et al. [48] reported that the precipitated material within the soil significantly promotes bonds among the soil particles, thus improving the bonding and cohesion of the soil, hence decreasing the friction angle of the soil particles. Wibisono et al. [49] also reported that clay in sandy soil brings about high cohesion and significantly reduces the internal friction angle. In addition, Asghari et al. [50] reported that the cementation process has no prominent impact on the internal friction angle.

\subsection{Unconfined Compressive Strength (UCS)}

Samples for the UCS tests were set up and treated in a similar way to the DS tests. The augmentation of the organic soil's compressive strength at various soybean concentrations is depicted in Figure 9. The results show that applying the calcite precipitation technique resulted in a significant improvement in the UCS. Strength ranging from 130 to $148 \mathrm{kPa}$ or a gain of 37 to $58 \%$ was obtained in this research compared to the untreated soil. The variation in soybean concentration also promoted a slight increase in the UCS. The rise in the strength of soil observed in this research was relatively lower than that of sandy soil. Putra et al. [24] reported that using a grouting solution composed of $2 \mathrm{~g} / \mathrm{L}$ of the urease enzyme and $1 \mathrm{~mol} / \mathrm{L}$ of the reagent resulted in an improvement in the strength of $205 \mathrm{kPa}$. This lower improvement in strength may cause a lower $\mathrm{pH}$ of 3 to 4 and organic content in the soil sample. Stocks-Fischer et al. [51] reported that the optimum $\mathrm{pH}$ for calcite promotion in calcite precipitation is 8.3 to 9.0. Previous studies also reported that a $\mathrm{pH}$ of 7.0 is the optimum condition for precipitated calcite [23]. In addition, the presence of the organic content coming from the soil sample and the undissolved soybeans may hamper the precipitation process; thus, the production of calcite is limited [27]. The results of the DS tests show a similar trend to that of the UCS tests conducted in this research. The UCS improvement also demonstrates an increase in cohesion. These results confirm that the precipitated calcite enhanced the cohesion of the soil particles [52]. 


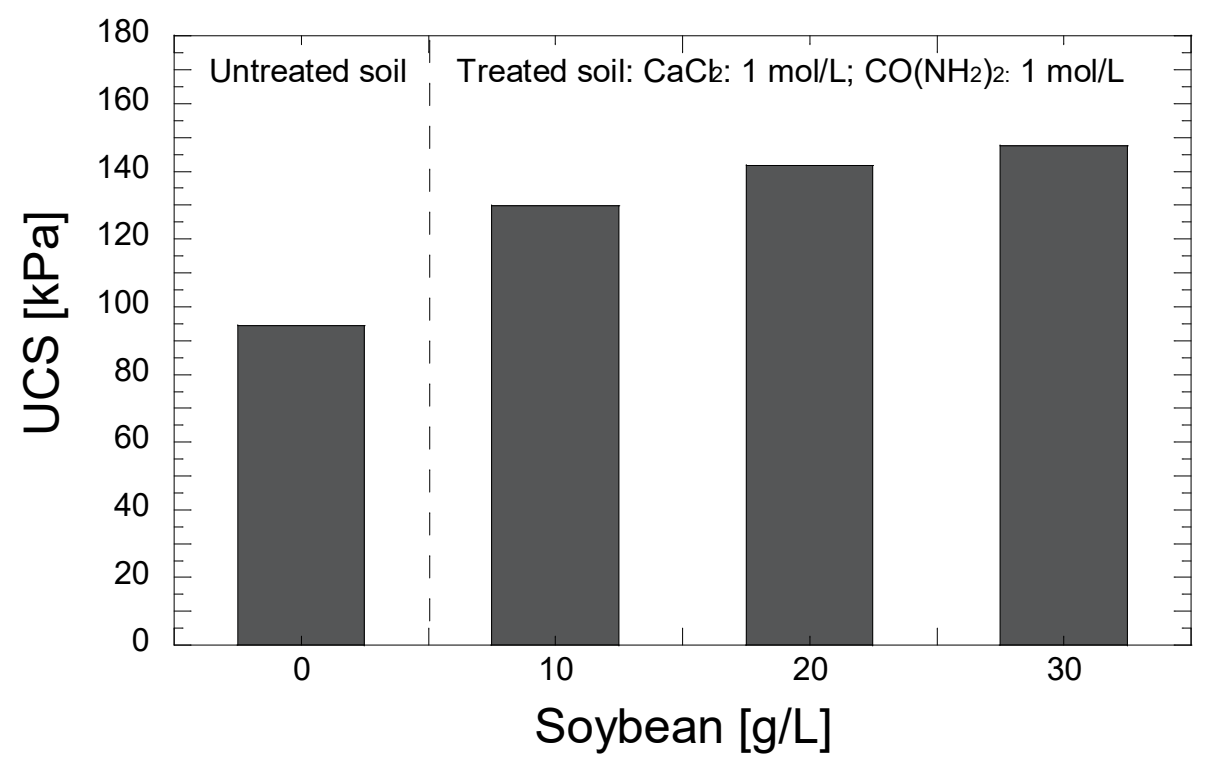

Figure 9. Results of UCS tests with various concentrations of soybeans.

\section{5. $\mathrm{pH}$ Measurement}

The $\mathrm{pH}$ measurement results are presented in Figure 10. The untreated organic soil was highly acidic, with a $\mathrm{pH}$ of 3.4. The soil treatment resulted in a slight improvement in $\mathrm{pH}$ with a maximum $\mathrm{pH}$ of 5.9. The lower improvement in $\mathrm{pH}$ may have been due to the fact that the precipitated solution was a weak base material with a maximum $\mathrm{pH}$ of 9, whereas the soil sample was strongly acidic [51]. This condition may also have had a significant effect on the precipitation process. A lower $\mathrm{pH}$ during the treatment process may have inhibited the hydrolysis process and thus, hampered calcite formation and reduced the calcite content [51].

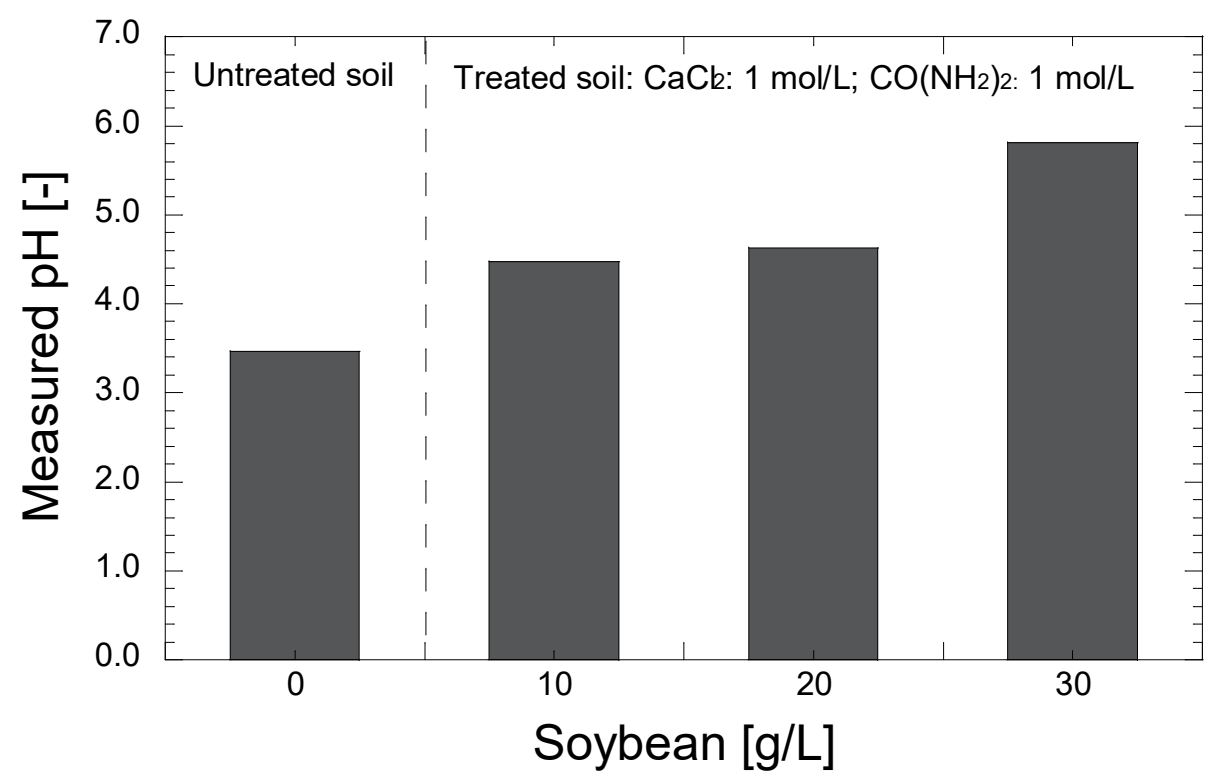

Figure 10. $\mathrm{pH}$ measurements of the organic soil.

\subsection{Scanning Electron Microscopy with Energy Dispersive Spectroscopy (SEM-EDS)}

SEM-EDS tests were performed to observe the particle morphology and composition of the precipitated material, organic soil, and treated soil. The outputs of the SEM-EDS tests are depicted in Figure 11. Figure 11a shows the morphology of the precipitated material and its components that were observed using SEM-EDS with a magnitude of 1000 times. The 
precipitated material was dominated by the amorphous, spherical, and rhombohedral form of the calcium carbonate. In addition, the fiber form, which is indicated as undissolved soybeans, was obtained from the SEM images. The amorphous and spherical shape indicates that the precipitation process was not optimum; hence, the calcination process was hampered [24]. Furthermore, the presence of the organic content, resulting in undissolved soybeans, may have inhibited the calcination process [27]. Therefore, the extraction method for soybean powder should be considered essential in the subsequent study.
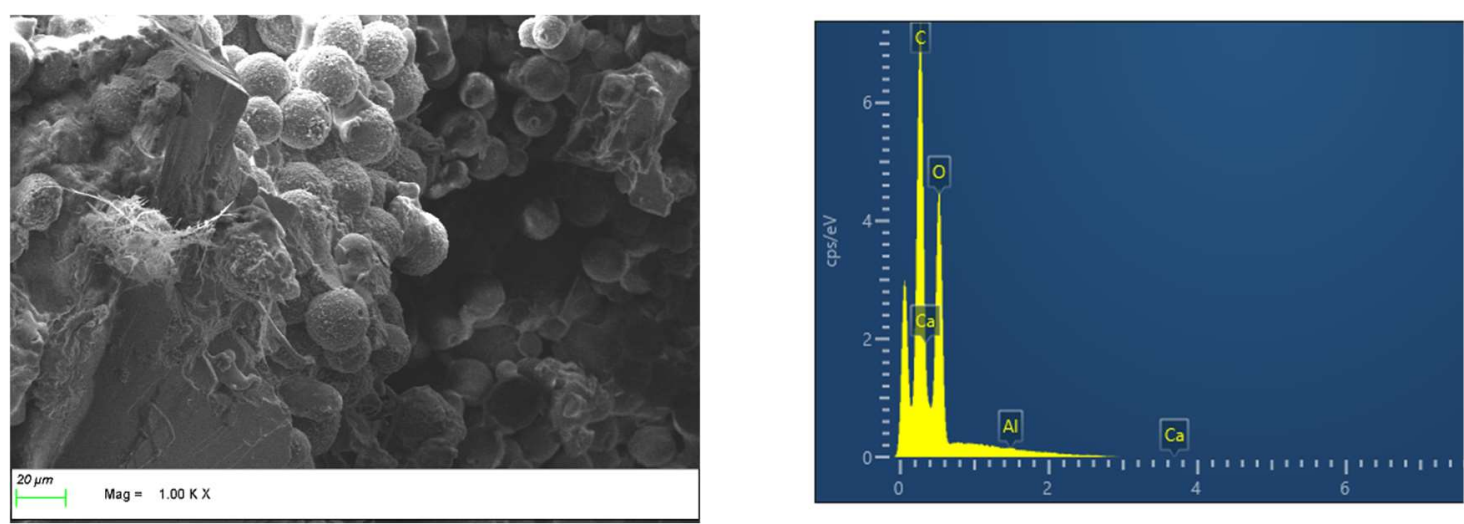

(a) Precipitated material
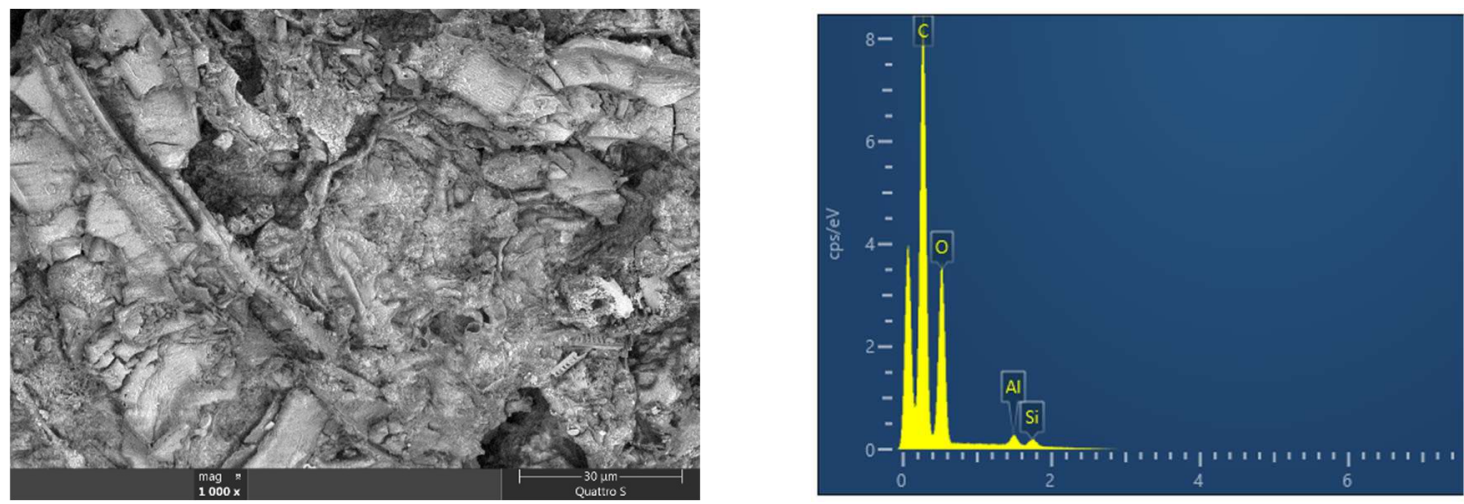

(b) Untreated organic soil
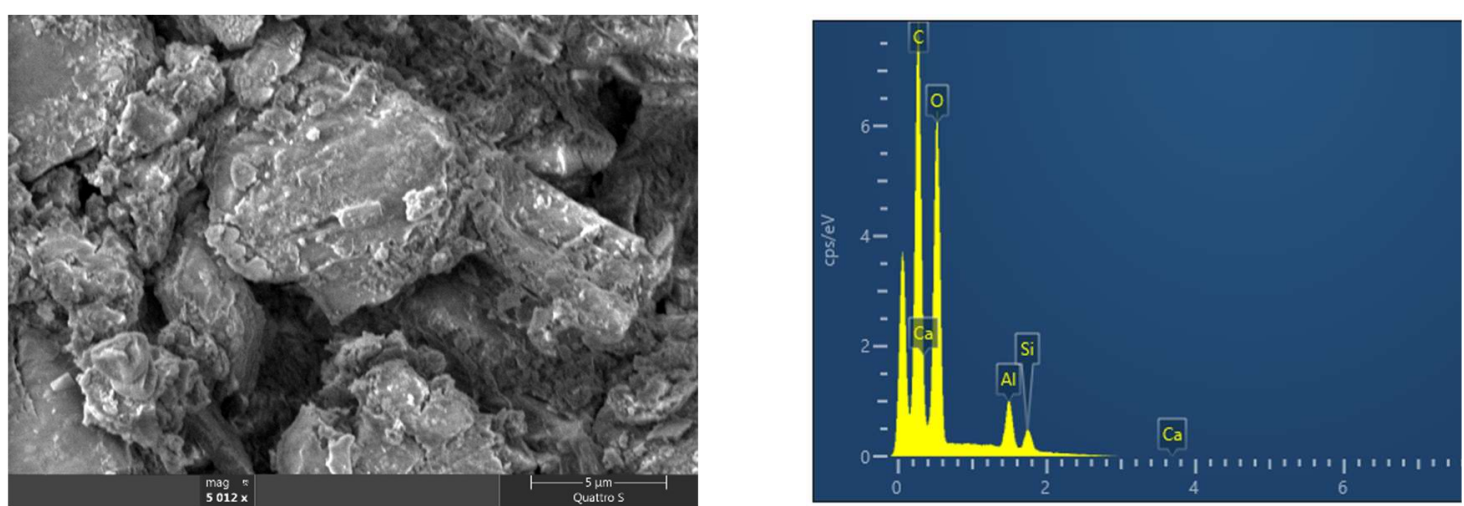

(c) Treated organic soil

Figure 11. SEM-EDS test results: (a) precipitated material, (b) untreated organic soil, and (c) treated organic soil.

The EDS results show that the precipitated material and organic soil had carbon, oxygen, and aluminum. In addition, the precipitated material was also composed of calcium. Meanwhile, the organic soil had silica. Figure 11b shows the SEM-EDS results for the unimproved organic soil. The sheet and form of the fiber were both clearly observed in the soil sample. Furthermore, Figure 11c shows the SEM-EDS results for the treated organic 
soil. The SEM tests were performed with a magnitude of 5000 times. The precipitated calcium carbonate was seen to be covering the sheet of organic soil. It filled the pores, bound soil particles, and thus increased the organic soil's strength. The SEM image clearly shows that the crystals precipitated on the organic soil's surface. However, the precipitated materials promoted in the treated were dominated by the amorphous form. It may also have impacted the presence of the organic content, resulting in soil samples and undissolved soybeans. The rhombohedral and spherical shape of the precipitated materials may have had difficulty forming in the high content of organic materials. The precipitated form and its location may have caused the lower effectivity of the improvement in the organic soil compared to that in the sandy soil, where the precipitated material ideally formed as calcite in the rhombohedral form on the contact surface of the soil particles [40]. Canacki et al. [40] also reported that in the organic soil treatment by the calcite precipitation method, the precipitated material formed on the surface and filled the pores of the organic soil.

\section{Conclusions}

The SCU-CP method was evaluated for its effectiveness as a soil-enhancement technique. Any experiments were performed to assess the applicability of soybean powder as a new material for a bio-catalyst. The hydrolysis-rated results confirm that the urease activity was linearly related to the increase in soybean concentration. A hydrolysis rate of $1600 \mathrm{u} / \mathrm{g}$ was obtained using $50 \mathrm{~g} / \mathrm{L}$ of soybeans. Hence, the soybeans had a high-enough hydrolysis rate to be used instead of commercial urease enzymes with the calcite precipitation method. The precipitation test results show that the soybean concentration is a crucial parameter in this method. The precipitation ratio significantly increased when the soybean concentration was increased from $5 \mathrm{~g} / \mathrm{L}$ to $20 \mathrm{~g} / \mathrm{L}$ and reached the optimum ratio of 20 to $30 \mathrm{~g} / \mathrm{L}$ of soybeans. In addition, the high concentration of soybeans was able to inhibit the precipitation process. The precipitation ratio dropped from 90 to $95 \%$ when 40 to $50 \mathrm{~g} / \mathrm{L}$ of soybeans were supplemented in the solution. The mechanical tests showed a significant amelioration in the parameters of the organic soil's shear strength. A shear strength improvement of 50\% was achieved in this study. A UCS and a cohesion of $148 \mathrm{kPa}$ and $50 \mathrm{kPa}$, respectively, were obtained for the treated samples of organic soil. This study confirms that SCU-CP is a practical approach to improve the organic soil's shear strength.

Author Contributions: H.P. conducted the experiment work, collected the data, and wrote the paper. E. and S. suggested the experimental methods and how to analyze the data. M.S. partly suggested the method and partly wrote the paper. D.H.Y.Y. partly conducted the experimental work. All authors have read and agreed to the published version of the manuscript.

Funding: This research was funded by the Ministry of Education, Culture, Research, and Technology of Indonesia, grant number 1/E1/KP.PTNBH/2021.

Acknowledgments: The authors acknowledge the managerial team of the Indonesian Institute of Science, especially the facilities and the scientific and technical assistance of the Integrated Laboratory of Bioproducts.

Conflicts of Interest: The authors declare no conflict of interest.

\section{References}

1. Kazemian, S.; Huat, B.B.K.; Prasad, A.; Barghchi, M. A state of art review of peat: Geotechnical engineering perspective. Int. J. Phys. Sci. 2011, 6, 1974-1981.

2. Kazemian, S.; Prasad, A.; Huat, B.B.K.; Ghiasi, V.; Ghareh, S. Effects of cement-sodium silicate system grout on tropical organic soils. Arab. J. Sci. Eng. 2012, 37, 2137-2148. [CrossRef]

3. Mochtar, N.E.; Yulianto, F.E. Pengaruh usia stabilisasi pada tanah gambut berserat yang distabilisasi dengan campuran $\mathrm{CaCO}_{3}$ dan pozolan. J. Tek. Sipil. 2014, 21, 57-64. [CrossRef]

4. Mochtar, N.E.; Yulianto, F.E. Compression behavior of fibrous peat stabilized with admixtures of lime $\mathrm{CaCO}_{3}+$ rice husk ash and lime $\mathrm{CaCO}_{3}+$ Fly Ash. Int. J. Adv. Sci. Eng. Inf. Technol. 2018, 8, 792-798. [CrossRef]

5. Muhardi; Wibisono, G.; Harist Febrie, R.Z. Peat soils stabilization using mixture to prevent peat fires. MATEC Web Conf. 2019, 276, 05006. [CrossRef] 
6. Shirin, M.S.; Ali, M.M.; Hasan, M.R.; Islam, S. Effect of organic soil on strength proeperties of compressed cement-soil block. J. Civ. Eng. Sci. Technol. 2017, 8, 16-23.

7. Hampton, M.B.; Edil, T.B. Strength gain of organic ground with cement-type binders. Geotech. Spec. Publ. 1998, 81, 135-148.

8. Koda, E.; Szymanski, A.; Wolski, W. Field and laboratory experience with the use of strip drains in organic soils. Can. Geotech. J. 1993, 30, 308-318. [CrossRef]

9. Rahmi, A.; Taib, S.N.L.; Sahdi, F. Investigation of the application of various water additive ratios on unconfined compressive strength of cement-stabilized amorphous peat at different natural moisture contents. Adv. Civ. Eng. 2018, 2018, 1945808. [CrossRef]

10. Fan, J.; Wang, D.; Qian, D. Soil-cement mixture properties and design considerations for reinforced excavation. J. Rock Mech. Geotech. Eng. 2018, 10, 791-797. [CrossRef]

11. Elwakil, A.Z.; Azzam, W.R. Soil improvement using grout walls. Alex. Eng. J. 2016, 55, 2741-2748. [CrossRef]

12. Riza, F.V.; Rahman, I.A.; Zaidi, A.M.A. Possibility of lime as a stabilizer in compressed earth brick (CEB). Int. J. Adv. Sci. Eng. Inf. Technol. 2011, 1, 582-585. [CrossRef]

13. Mujah, D.; Shahin, M.A.; Cheng, L. State-of-the-art review of biocementation by microbially induced calcite precipitation (MICP) for soil stabilization. Geomicrobiol. J. 2016, 34, 524-537. [CrossRef]

14. DeJong, J.T.; Fritzges, M.B.; Nüsslein, K. microbially induced cementation to control sand response to undrained shear. J. Geotech. Geoenviron. Eng. 2006, 132, 1381-1392. [CrossRef]

15. Soon, N.W.; Lee, L.M.; Khun, T.C.; Ling, H.S. Factors affecting improvement in engineering properties of residual soil through microbial-induced calcite precipitation. J. Geotech. Geoenviron. Eng. 2014, 140, 04014006. [CrossRef]

16. Cheng, L.; Shahin, M.A.; Asce, M.; Mujah, D.; Asce, M.; Mujah, D. Influence of key environmental conditions on microbially induced cementation for soil stabilization. J. Geotech. Geoenviron. Eng. 2017, 143, 04016083. [CrossRef]

17. Neupane, D.; Yasuhara, H.; Kinoshita, N.; Ando, Y. Distribution of mineralized carbonate and its quantification method in enzyme mediated calcite precipitation technique. Soils Found. 2015, 55, 447-457. [CrossRef]

18. Oliveira, P.J.V.; Freitas, L.D.; Carmona, J.P.S.F. Effect of soil type on the enzymatic calcium carbonate precipitation process used for soil improvement. J. Mater. Civ. Eng. 2016, 29, 04016263. [CrossRef]

19. Neupane, D.; Yasuhara, H.; Kinoshita, N.; Unno, T. Applicability of enzymatic calcium carbonate precipitation as a soilstrengthening technique. J. Geotech. Geoenviron. Eng. 2013, 139, 2201-2211. [CrossRef]

20. Simatupang, M.; Okamura, M. Liquefaction resistance of sand remediated with carbonate precipitation at different degrees of saturation during curing. Soils Found. 2017, 57, 619-631. [CrossRef]

21. Putra, H.; Yasuhara, H.; Kinoshita, N. Optimum condition for the application of enzyme-mediated calcite precipitation technique as soil improvement method. Int. J. Adv. Sci. Eng. Inf. Technol. 2017, 7, 2145-2151. [CrossRef]

22. Al Imran, M.; Nakashima, K.; Kawasaki, S. Bio-mediated soil improvement using plant derived enzyme in addition to magnesium ion. Crystals 2011, 11, 516. [CrossRef]

23. Yasuhara, H.; Hayashi, K.; Okamura, M. Evolution in mechanical and hydraulic properties of calcite-cemented sand mediated by biocatalyst. In Geo-Frontiers 2011; American Society of Civil Engineers: Dallas, TX, USA, 2011; pp. 3984-3992. [CrossRef]

24. Putra, H.; Yasuhara, H.; Kinoshita, N.; Hirata, A. Optimization of enzyme-mediated calcite precipitation as a soil-improvement technique: The effect of aragonite and gypsum on the mechanical properties of treated sand. Crystals 2017, 7, 59. [CrossRef]

25. Chandra, A.; Ravi, K. Effect of magnesium incorporation in enzyme-induced carbonate precipitation (EICP) to improve shear strength of soil. In Advances in Computer Methods and Geomechanics; Lecture Notes in Civil Engineering; Springer: Singapore, 2020; pp. 333-346. [CrossRef]

26. Putra, H.; Yasuhara, H.; Kinoshita, N.; Hirata, A. Application of magnesium to improve uniform distribution of precipitated minerals in 1-m column specimens. Geomech. Eng. 2017, 12, 803-813. [CrossRef]

27. Sulistiawati, H.B.; Yasuhara, H.; Kinoshita, N.; Putra, H.; Johan, E. Examination of calcite precipitation using plant-derived urease enzyme for soil improvement. Int. J. Geomate 2020, 19, 231-237. [CrossRef]

28. Almajed, A.; Lateef, M.A.; Moghal, A.A.B.; Lemboye, K. State-of-the-art review of the applicability and challenges of microbialinduced calcite precipitation (MICP) and enzyme-induced calcite precipitation (EICP) techniques for geotechnical and geoenvironmental applications. Crystals 2021, 11,370. [CrossRef]

29. Dilrukshi, R.A.N.; Nakashima, K.; Kawasaki, S. Soil improvement using plant-derived urease-induced calcium carbonate precipitation. Soils Found. 2018, 58, 894-910. [CrossRef]

30. Larsen, J.; Poulsen, M.; Lundgaard, T.; Agerbaek, M. Plugging of fractures in chalk reservoirs by enzyme-induced calcium carbonate precipitation. SPE Prod. Oper. 2008, 23, 478-483. [CrossRef]

31. Cuccurullo, A.; Gallipoli, D.; Bruno, A.W.; Augarde, C.; Hughes, P.; La Borderie, C. Earth stabilisation via carbonate precipitation by plant-derived urease for building applications. Geomech. Energy Environ. 2020, 100230. [CrossRef]

32. Gao, Y.; He, J.; Tang, X.; Chu, J. Calcium carbonate precipitation catalyzed by soybean urease as an improvement method for fine-grained soil. Soils Found. 2019, 59, 1631-1637. [CrossRef]

33. Pratama, G.B.S.; Yasuhara, H.; Kinoshita, N.; Putra, H. Application of soybean powder as urease enzyme replacement on EICP method for soil improvement technique. IOP Conf. Ser. Earth Environ. Sci. 2021, 622, 012035. [CrossRef]

34. Akiyama, M.; Kawasaki, S. Microbially mediated sand solidification using calcium phosphate compounds. Eng. Geol. 2012, 137-138, 29-39. [CrossRef] 
35. Paassen, L.A.; Van Daza, C.M.; Staal, M.; Sorokin, D.Y.; Van Der Zon, W.; Van Loosdrecht, M.C.M. Potential soil reinforcement by biological denitrification. Ecol. Eng. 2010, 36, 168-175. [CrossRef]

36. Sidik, W.S.; Canakci, H.; Kilic, I.H.; Celik, F. Applicability of biocementation for organic soil and its effect on permeability. Geomech. Eng. 2014, 7, 649-663. [CrossRef]

37. Canakci, H.; Sidik, W.; Kilic, I.H. Bacterail calcium carbonate precipitation in peat. Arab. J. Sci. Eng. 2015, 40, 2251-2260. [CrossRef]

38. Chen, M. Evaluating mechanical strength of peat soil treated by fiber incorporated bio-cementation. Int. J. Geomate 2021, 20, 121-127. [CrossRef]

39. Canakci, H.; Hamed, M.; Celik, F.; Sidik, W.; Eviz, F. Friction characteristics of organic soil with construction materials. Soils Found. 2016, 56, 965-972. [CrossRef]

40. Canakci, H.; Sidik, W.; Halil Kilic, I. Effect of bacterial calcium carbonate precipitation on compressibility and shear strength of organic soil. Soils Found. 2015, 55, 1211-1221. [CrossRef]

41. ASTM. Standard Practice for Classification of Soils for Engineering Purposes (Unified Soil Classification System); ASTM: West Conshohocken, PA, USA, 2006; Available online: www.scribd.com (accessed on 27 July 2021).

42. Whiffin, V.S. Microbial $\mathrm{CaCO}_{3}$ Precipitation for the Production of Biocement; Murdoch University: Perth, Australia, 2004.

43. ASTM International. ASTM D2976, Standard Test Method for $p H$ of Peat Materials; ASTM: West Conshohocken, PA, USA, 1998. Available online: www.astm.org (accessed on 27 July 2021).

44. Neupane, D.; Yasuhara, H.; Kinoshita, N. Evaluation of enzyme mediated calcite grouting as a possible soil improvement technique. Comput. Methods Recent Adv. Geomech. 2015, 4, 1169-1172.

45. Harrita, S.; Priya, V.V.; Gayathri, R. Assessment of urease activity in soya bean products. Drug Invent. Today 2018, 10, 2045-2047.

46. Cheng, L.; Shahin, M.A.; Cord-Ruwisch, R. Soil Stabilisation by Microbial-Induced Calcite Precipitation (MICP): Investigation into some physical and environmental aspects. Int. Congr. Environ. Geotech. 2014, 64, 1105-1112.

47. Achal, V.; Mukherjee, A.; Basu, P.C.; Reddy, M.S. Strain improvement of Sporosarcina pasteurii for enhanced urease and calcite production. J. Ind. Microbiol. Biotechnol. 2009, 36, 981-988. [CrossRef]

48. Putra, H.; Yasuhara, H.; Kinoshita, N.E.; Sudibyo, T. Improving shear strength parameters of sandy soil using enzyme-mediated calcite precipitation technique. Civ. Eng. Dimens. 2018, 20, 91. [CrossRef]

49. Wibisono, G.; Nugroho, S.A.; Umam, K. The influence of sand's gradation and clay content of direct sheart test on clayey sand. IOP Conf. Ser. Mater. Sci. Eng. 2018, 316, 012038. [CrossRef]

50. Asghari, E.; Toll, D.; Haeri, S. Effect of cementation on the shear strength of Tehran gravelly sand using triaxial tests. J. Sci. Islam. Repub. Iran. 2004, 15, 65-72.

51. Stocks-Fischer, S.; Galinat, J.K.; Bang, S.S. Microbiological precipitation of $\mathrm{CaCO}_{3}$. Soil Biol. Biochem. 1999, 31, $1563-1571$. [CrossRef]

52. Wibawa, A.; Hisyam, E. Pengaruh penambahan limbah gypsum terhadap nilai kuat geser tanah lempung. Forum. Prof. Tek. Sipil. 2015, 3, 65-71. 